Доходы бюджета муниципального образования «город Ульяновск» на 2018 год определились в объёме 8920 980,8 тыс. рублей, на 2019 год - 8295 972,7 тыс. рублей, на 2020 год - 8687 698,2 тыс. рублей.

Расходы на 2018 год предусмотрены в сумме 9247 895,8 тыс. рублей, на 2019 год - 8295 972,7 тыс. рублей, на 2020 год - 8687 698,2 тыс. рублей.

Дефицит бюджета муниципального образования «город Ульяновск» планируется на 2018 год в сумме 326,9 тыс. рублей (7 \% от объёма налоговых и неналоговых доходов бюджета муниципального образования «город Ульяновск»).

На 2019 и 2020 годы предлагается бездефицитный бюджет муниципального образования «город Ульяновск». Результатом работы профильных служб и комитетов Думы города Ульяновска стал более сбалансированный вариант бюджета города (по сравнению с 2017 годом [3]), сформированный в условиях острого бюджетного кризиса.

$$
* * *
$$

1. Проект решения Ульяновской Городской Думы «О бюджете муниципального образования «город Ульяновск» на 2018 год и на плановый период 2019 и 2020 годов»

2. Вершинин Ю.Б., Вершинина Е.Л. О мерах по обеспечению финансирования основных статей бюджета муниципального образования «Город Ульяновск». Научный диалог: Экономика и менеджмент. Сборник научных трудов по материалам VI международной научной конференции. Санкт-Петербург, 08 мая 2017 г. Издательство: Центр научных конференций Международной научно-исследовательской Федерации "Общественная наука" Страницы: 9-10 DOI: 10.18411/spc-805-2017-04

3. Вершинин Ю.Б., Вершинина Е.Л. О соотношении доходных поступлений в бюджет муниципального образования «Город Ульяновск» с его расходными обязательствами. Научный диалог: Экономика и менеджмент. Сборник научных трудов по материалам VI международной научной конференции. Санкт-Петербург, 08 мая 2017 г. DOI: 10.18411/spc-8-05-2017-03

\title{
Вершинин Ю.Б., Вершинина Е.Л. \\ О структуре доходных поступлений в бюджет муниципального образования «Город Ульяновск» в 2018 году
}

Ульяновский государственный университет (Россия, Ульяновск)

doi:10.18411/spc-8-11-2017-04

idsp: 000001:spc-8-11-2017-04

Исходной базой для разработки прогноза доходов бюджета являются показатели бюджета текущего года с внесёнными изменениями, предложения главных администраторов доходов, оценка ожидаемого поступления налогов и других обязательных платежей в 2017 году, данные УФНС по Ульяновской области о налоговой базе зачисляемых в бюджет города налогов за 2016 год и параметры прогноза социально-экономического развития муниципального образования «город Ульяновск» и Ульяновской области на 2018 год и на плановый период до 2020 года [1].

Формирование проекта бюджета города на 2018 - 2020 годы произведено в соответствии с нормативами отчислений, установленными в бюджеты городских округов БК РФ, проектом закона Ульяновской области «Об областном бюджете Ульяновской области на 2018 год и на плановый период 2019 и 2020 годов», законом Ульяновской области от 04.10.2011 № 142-3О «О межбюджетных отношениях в Ульяновской области» (с изменениями) [2]:

по местным налогам: земельный налог - 100 \%; налог на имущество физических лиц $-100 \%$;

по федеральным налогам и сборам:

- налог на доходы физических лиц - $30 \%$, в том числе в соответствии с Бюджетным кодексом - $15 \%$, законом Ульяновской области от 
04.10.2011

№ 142-3О «О межбюджетных отношениях в Ульяновской области» (с изменениями) - $15 \%$;

- налог на доходы физических лиц с доходов, полученных физическими лицами, являющимися иностранными гражданами, осуществляющими трудовую деятельность по найму у физических лиц на основании патента - $15 \%$ в соответствии с законом УО от 04.10.2011 № 142-30 «О межбюджетных отношениях в Ульяновской области» (с изменениями);

- доходы от уплаты акцизов на автомобильный бензин, дизельное топливо, моторные масла для дизельных и карбюраторных (инжекторных) двигателей - в соответствии с установленным нормативом распределения в размере 1,3319 доходов консолидированного бюджета Ульяновской области от указанного налога в соответствии с проектом закона Ульяновской области «Об областном бюджете Ульяновской области на 2018 год и на плановый период 2019 и 2020 годов» (письмо Министерства финансов Ульяновской области от 07.08.2017 №73-ИОГВ02-01/1910 исх);

- государственная пошлина по делам, рассматриваемым в судах общей юрисдикции, мировыми судьями (за исключением государственной пошлины по делам, рассматриваемым Верховным Судом Российской Федерации) - 100\%;

- государственная пошлина за выдачу органом местного самоуправления городского округа специального разрешения на движение по автомобильным дорогам транспортных средств, осуществляющих перевозки опасных, тяжеловесных и (или) крупногабаритных грузов, зачисляемая в бюджеты городских округов - 100\%;

- по налогам, предусмотренным специальными налоговыми режимами: ЕНВД - 100\%; налог, взимаемый в связи с применением патентной системы налогообложения - $100 \%$; единый сельскохозяйственный налог - $100 \%$; налог, взимаемый с применением упрощённой системы налогообложения - 5\% в соответствии с законом Ульяновской области от 04.10.2011 № 142-3О «О межбюджетных отношениях в Ульяновской области» (с изменениями).

$$
* * *
$$

1. Проект решения Ульяновской Городской Думы «О бюджете муниципального образования «город Ульяновск» на 2018 год и на плановый период 2019 и 2020 годов».

2. Вершинин Ю.Б., Вершинина Е.Л. О структуре доходных поступлений в бюджет муниципального образования «Город Ульяновск». Научный диалог: Экономика и менеджмент. Сборник научных трудов по материалам V международной научной конференции. Санкт-Петербург, 08 апреля 2017 г. Стр. 19-20 DOI: 10.18411/spc-8-04-2017-08

\section{Вершинин Ю.Б., Вершинина Е.Л. \\ Оценка поступлений от налога на доходы физических лиц в бюджет города Ульяновска в 2018 году}

Ульяновский государственньй университет (Россия, Ульяновск)

doi:10.18411/spc-8-11-2017-05

idsp: 000001:spc-8-11-2017-05

Вопросы сбалансированности налоговых поступлений в бюджет муниципального образования для оценки деятельности муниципальных учреждений финансовых показателей всегда являлись важными объектами исследования [1].

В 2018 году прогноз поступления налога определён в сумме 3037991,3 тыс. рублей, что лучше показателей 2017 года [2].

Прогнозный расчёт был произведён исходя из оценки ожидаемого поступления налога в 2017 году в сумме 2956924,0 тыс. рублей с применением норматива 